\title{
Abattoir study of genital diseases of female Black Bengal goats
}

\author{
ABMJ Uddin', M Nooruzzaman, T. Akter, MAHNA Khan and MM Hossain* \\ Department of Pathology, Faculty of Veterinary Science, Bangladesh Agricultural \\ University, Mymensingh-2202, Bangladesh
}

\begin{abstract}
Pathological investigation of genital diseases in Black Bengal goats (Capra hircus) was done using slaughterhouse materials. A total of 256 female genitalia were collected from slaughterhouses of Kishoreganj district of Bangladesh during October 2016 to December 2018. The gross pathological changes were recorded and tissues from the affected organs were collected for histopathology. A total of $56(21.9 \%)$ female genitalia showed one or more of the 84 different pathological changes. The prevalence of reproductive diseases increased with age: the highest number of lesions (34) was recorded in animals aged 19-24 months. The uterus showed the highest number of pathological lesions (44) followed by ovary (31), fallopian tube (5), cervix (2) and vagina (2). Major pathological changes were luteal cyst $(7.4 \%)$, endometritis $(6.3 \%)$ and pyometra (7.0\%). (Bangl. vet. 2019. Vol. 36, No. 1 - 2, 8 - 19)
\end{abstract}

\section{Introduction}

In 2017 - 2018, there were about 26.1 million goats in Bangladesh, of which about 90\% were Black Bengal goats (BBS, 2019). The ability of the breed to produce offspring within a short time makes the Black Bengal goat the most popular breed (Hasan et al., 2015). Each year 20,400 tonnes goat meat is produced, which accounts for $25 \%$ of total red meat in Bangladesh (Ferdous et al., 2012). Reports on genital disorders in goats on abattoir materials are few (Bhuiyan et al., 1988; Das et al., 1979; Kadu and Kaikini, 1988; Nair and Raja, 1972; Rahman et al., 2010; Roy et al., 2001; Sattar and Khan, 1988; Srivastava et al., 1985). Characterization of gross and histopathological changes of female reproductive organs demand further studies. Diseases of genital tract significantly affect productivity. The present investigation was undertaken to study the prevalence of reproductive disorders in female Black Bengal goats and the gross and histopathological changes in genital organs.

\section{Materials and Methods}

\section{Sample collection}

A total of 256 reproductive organs of female Black Bengal goats were collected from slaughterhouses of Kishoreganj districts of Bangladesh during October 2016 to

\footnotetext{
1Department of Livestock Services, Bangladesh

*Corresponding author:- E-mail: mmhossain04@yahoo.com.au
}

DOI: https://doi.org/10.3329/bvet.v36i1-2.55745 
December 2018. Ages and body weights were recorded. The animals were divided into four groups, $\leq 6$ months, 7 - 12 months, 13 - 18 months and 19 - 24 months. Animals were weighing between $5.2 \pm 0.1 \mathrm{Kg}$ and $10.9 \pm 0.7 \mathrm{Kg}$. A total of 64 genitalia were collected for each $\mathrm{g}$ roup. Following slaughter, the genitalia were placed immediately in ice box and transported to the laboratory. Tissues were collected in $10 \%$ neutral buffered formalin for histopathology.

\section{Gross pathology}

Gross evaluation was carried out by palpation, incision and visual appraisal. Lesions were described by size, shape, colour, consistency, smell or location.

\section{Histopathology}

The collected tissues were fixed in $10 \%$ neutral buffered formalin for at least seven days. Samples were processed, sectioned and stained with haematoxylin and eosin as described by Luna (1986). The slides were examined under photomicroscope (ZEISS Primo Star).

\section{Statistical analysis}

Graphs were prepared using GraphPad Prism 5.0 software.

\section{Results and Discussion}

\section{Prevalence of reproductive diseases}

Out of 256 female genitalia of Black Bengal goats 56 (21.9\%) showed one or more pathological lesions. A total of 84 different pathological conditions were recorded. The number of reproductive diseases increased with age (Fig. 1a). The highest number (n = 34) was recorded at $19-24$ months age followed by $13-18$ months ( $\mathrm{n}=27), 7-12$ months $(n=18)$ and $\leq 6$ months $(n=5)$. The highest number of pathological conditions were in the uterus $(\mathrm{n}=44 ; 52.3 \%)$ followed by ovary $(\mathrm{n}=31 ; 36.9 \%)$, fallopian tube (n $=5 ; 5.9 \%)$, cervix $(n=2 ; 3.7 \%)$ and vagina $(n=2 ; 3.7 \%)$ (Fig. $1 \mathrm{~b})$. A high prevalence of reproductive disorders including infections was reported in an abattoir survey in goats from Mymensingh district (Rahman et al., 2010). A total of $62.2 \%$ uterine affections was described including 35.2\% uterine disorders and $27 \%$ uterine infections (Rahman et al., 2010). A high frequency (33.3\%) of uterine disorders has been reported by Bhuiyan et al. (1988). A lower (11.8\%) frequency of ovarian lesions was detected by Rahman et al. (2010).

The conditions and their frequencies are presented in Fig. 1c and Table 1. In ovary, the luteal cyst $(n=19)$ was the most common pathological condition. Other ovarian lesions included parovarian cyst $(n=3)$, granulosa cell tumour $(n=2)$ and dysgerminoma $(n=1)$, ovarian hypoplasia $(n=2)$, ovaro-bursal adhesion $(n=2)$ and chronic oophoritis $(\mathrm{n}=2)$. The pathological conditions in the fallopian tube were salpingitis $(n=3)$, hydrosalpinx $(n=1)$ and pyosalpinx $(n=1)$. In uterus, pyometra $(n$ $=18$ ) was the most frequently detected lesion. Other uterine lesions were hydrometra 
$(n=6)$, mucometra $(n=4)$, acute endometritis $(n=5)$, sub-acute endometritis $(n=4)$ and chronic endometritis $(n=7)$. In the cervix, acute and chronic cervicitis were recorded, one in each case. One case of granular vaginitis and one Bartholin gland cyst was seen, associated with vaginitis. The genitalia showed wide range of pathological conditions, the luteal cyst, pyometra and endometritis being the most common.

a

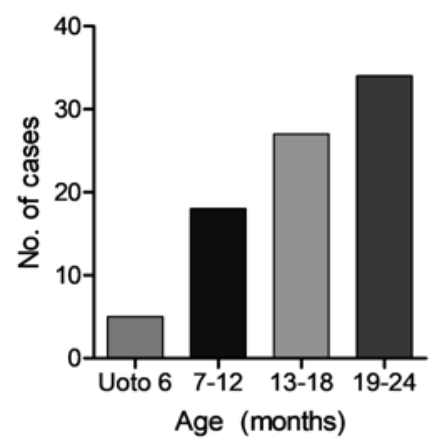

C

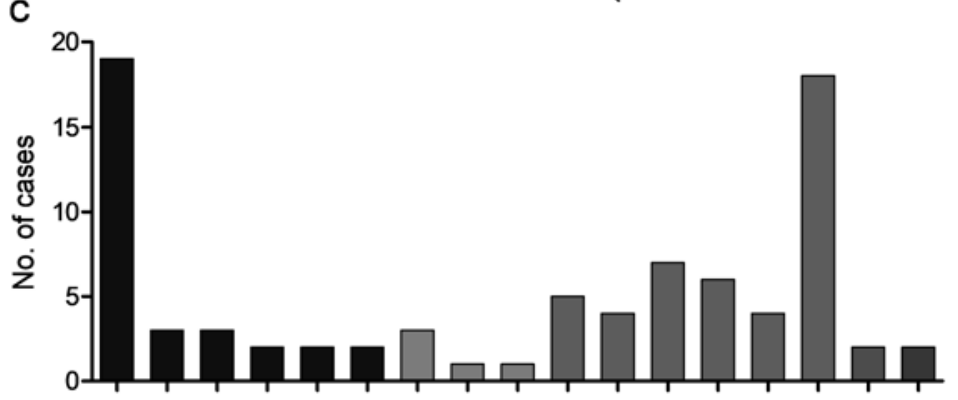

b

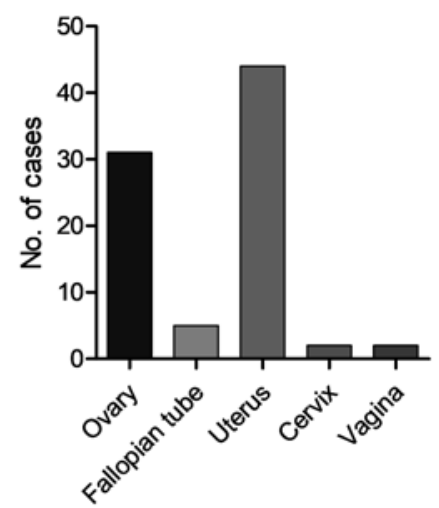

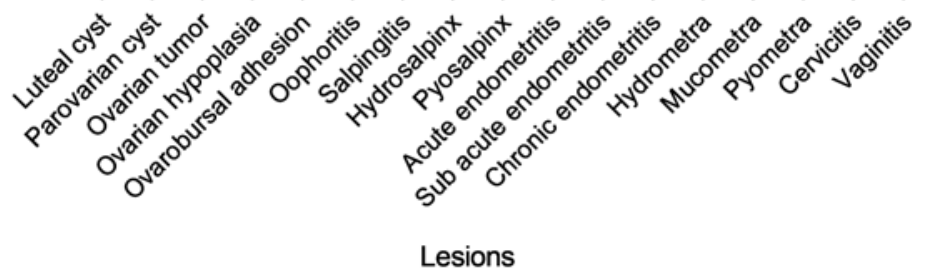

Fig. 1: Prevalence of pathological conditions in reproductive tracts of female Black Bengal goats. (a) Age distribution of conditions, (b) organ distribution of conditions and (c) overall distribution of conditions.

\section{Gross and histological changes in Black Bengal goats}

\section{Ovary}

Luteal cyst was recorded in 19 (7.4\%) cases. Grossly, the luteal cyst was characterized by cystic structures $14-18 \mathrm{~mm}$ in diameter protruding from the surface of the ovary with a thick cyst wall (Fig. 2a). At histopathology, an inner layer of fibrous connective tissue separated the luteinized cells from the lumen (Fig. 2b). The prevalence of luteal 
cyst was higher than two former studies, which detected $0.2 \%$ and $0.1 \%$ luteal cyst in goats, respectively (Chand and Chauhan, 1979; Sattar and Khan, 1988).

Table 1: List of pathological conditions in the female reproductive system of Black Bengal goats

\begin{tabular}{|c|c|c|c|c|c|c|c|}
\hline \multirow[t]{2}{*}{ Organ } & \multirow[t]{2}{*}{ Pathological condition } & \multicolumn{5}{|c|}{ No. of cases } & \multirow{2}{*}{$\begin{array}{c}\text { Prevalence } \\
(\%)\end{array}$} \\
\hline & & $\leq 6 \mathrm{~m}$ & $7-12 \mathrm{~m}$ & $13-18 \mathrm{~m}$ & $19-24 \mathrm{~m}$ & Total & \\
\hline \multirow[t]{8}{*}{ Ovary } & Luteal cyst & - & 5 & 5 & 9 & 19 & 7.4 \\
\hline & Parovarian cyst & 1 & 1 & 1 & & 3 & 1.2 \\
\hline & Ovarian tumour: & & & & & & \\
\hline & a. Granulosa cell tumour & & 1 & 1 & & 2 & 0.8 \\
\hline & b. Dysgerminoma & & & & 1 & 1 & 0.4 \\
\hline & Ovarian hypoplasia & 1 & & 1 & & 2 & 0.8 \\
\hline & Ovaro-bursal adhesion & 1 & & & 1 & 2 & 0.8 \\
\hline & Chronic oophoritis & & 1 & 1 & & 2 & 0.8 \\
\hline \multirow{3}{*}{$\begin{array}{l}\text { Fallopian } \\
\text { tube }\end{array}$} & Salpingitis & 1 & & 1 & 1 & 3 & 1.2 \\
\hline & Hydrosalpinx & & & 1 & & 1 & 0.4 \\
\hline & Pyosalpinx & & 1 & & & 1 & 0.4 \\
\hline \multirow[t]{6}{*}{ Uterus } & Acute endometritis & 1 & 1 & 2 & 1 & 5 & 2.0 \\
\hline & Sub-acute endometritis & & & 2 & 2 & 4 & 1.6 \\
\hline & Chronic endometritis & & 1 & 2 & 4 & 7 & 2.7 \\
\hline & Hydrometra & & 1 & 1 & 4 & 6 & 2.3 \\
\hline & Mucometra & & 1 & 1 & 2 & 4 & 1.6 \\
\hline & Pyometra & & 4 & 6 & 8 & 18 & 7.0 \\
\hline \multirow[t]{2}{*}{ Cervix } & Acute cervicitis & & 1 & & & 1 & 0.4 \\
\hline & Chronic cervicitis & & & 1 & & 1 & 0.4 \\
\hline \multirow[t]{3}{*}{ Vagina } & Granular vaginitis & & & 1 & & 1 & 0.4 \\
\hline & Bartholin gland cyst & & & & 1 & 1 & 0.4 \\
\hline & Total & 5 & 18 & 27 & 34 & 84 & \\
\hline
\end{tabular}

Three cases $(1.2 \%)$ of parovarian cysts were detected. Grossly, parovarian cyst appeared as bright pearl white in colour and about $2-4 \mathrm{~mm}$ in diameter. The cyst contained clear fluid (Fig. 2c). Two parovarian cysts were detected at the anterior pole of the ovary and diagnosed as epoophoron cyst. Another cyst was at the oviductal fimbria and diagnosed as paroophoron cyst. Microscopically, the cysts showed low cuboidal epithelium supported by two layers of smooth muscle, mesenchymal cell and loose connective tissue (Fig. 2d). Lyngset (1968) reported ovarian cyst in $2.4 \%$ of slaughtered goats, which were unilateral or single and between 1.2 and $3.7 \mathrm{~cm}$ diameter. A prevalence of parovarian cyst from 0.1 - 1.4\% was recorded (Nair and Raja, 1972; Sattar and Khan, 1988). 

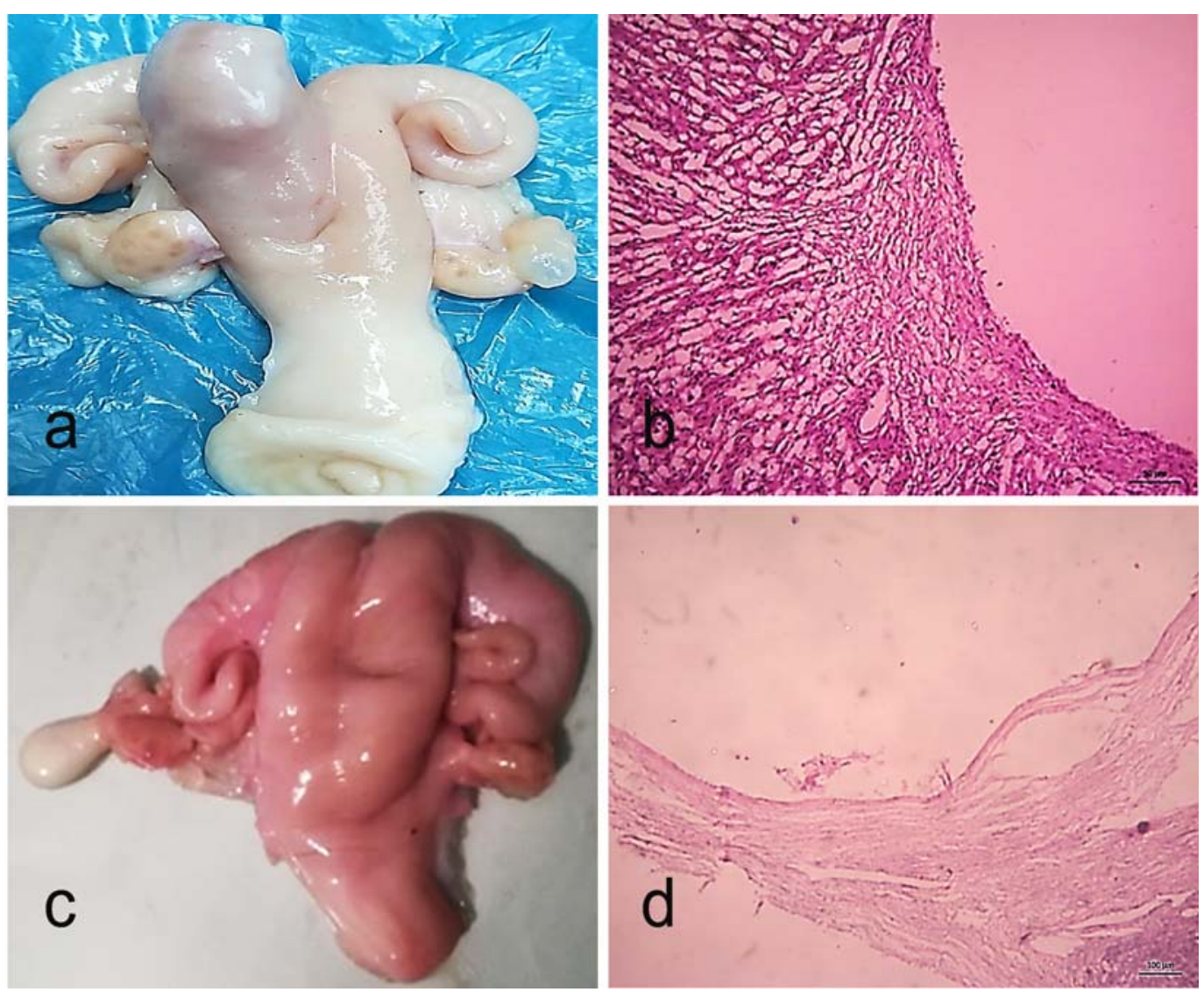

Fig. 2: Ovary of Black Bengal goat showing luteal cyst and parovarian cyst. (a) Luteal cyst appeared as milky white single cyst $16 \mathrm{~mm}$ in diameter, (b) section of ovary showing luteal cystic cavities lined by a thin fibrous layer surrounded by luteinized cells and absence of an ovum, (c) the parovarian cysts contained cream-white or watery fluid, and (d) section of a parovarian cyst showing cyst wall consisting of low cuboidal epithelium supported by two layers of smooth muscle.

Two cases $(0.8 \%)$ of ovaro-bursal adhesion were identified, characterized by adherence of the ovarian bursa to the ovary. Microscopically, fibrous connective tissue proliferation was beneath the germinal epithelium in both cases. Higher rates $(3.0 \%$ and $2.7 \%$ ) of ovaro-bursal adhesion in goats were reported (Das et al., 1979; Sattar and Khan, 1988).

Two cases of ovarian hypoplasia were recorded where the ovary was smaller $(0.5 \mathrm{~cm})$ than normal $(1.3 \mathrm{~cm})$ (Fig. 3a). Microscopically, the ovarian stroma of the affected ovaries was fibrosed and the follicles were almost absent (Fig. 3b). The prevalence of ovarian hypoplasia in Black Bengal goats was slightly higher than the two previous reports $(0.6 \%$ and $0.4 \%)$ (Lyngset, 1968; Sattar and Khan, 1988). Three (1.2\%) cases of ovarian tumour were identified. The ovary with granulosa cell tumour was enlarged $(4.5 \mathrm{~cm})$ and the tumour mass was hard in consistency (Fig. 3c). Microscopically, neoplastic cells with hyper chromatic nuclei, mitosis and hypercellularity were found 
(Fig. 3d). A case of dysgerminoma was identified, which appeared like a tumour with hard consistency. The ovary was larger $(4.2 \mathrm{~cm})$ than normal. Microscopically, the dysgerminoma was characterized by spherical cells with hyperchromatic nuclei and mitotic figures resembling seminoma. The prevalence of granulosa cell tumour $(1.2 \%)$ was lower than the incidence (5.9\%) reported by Rahman et al. (2010) in goats.
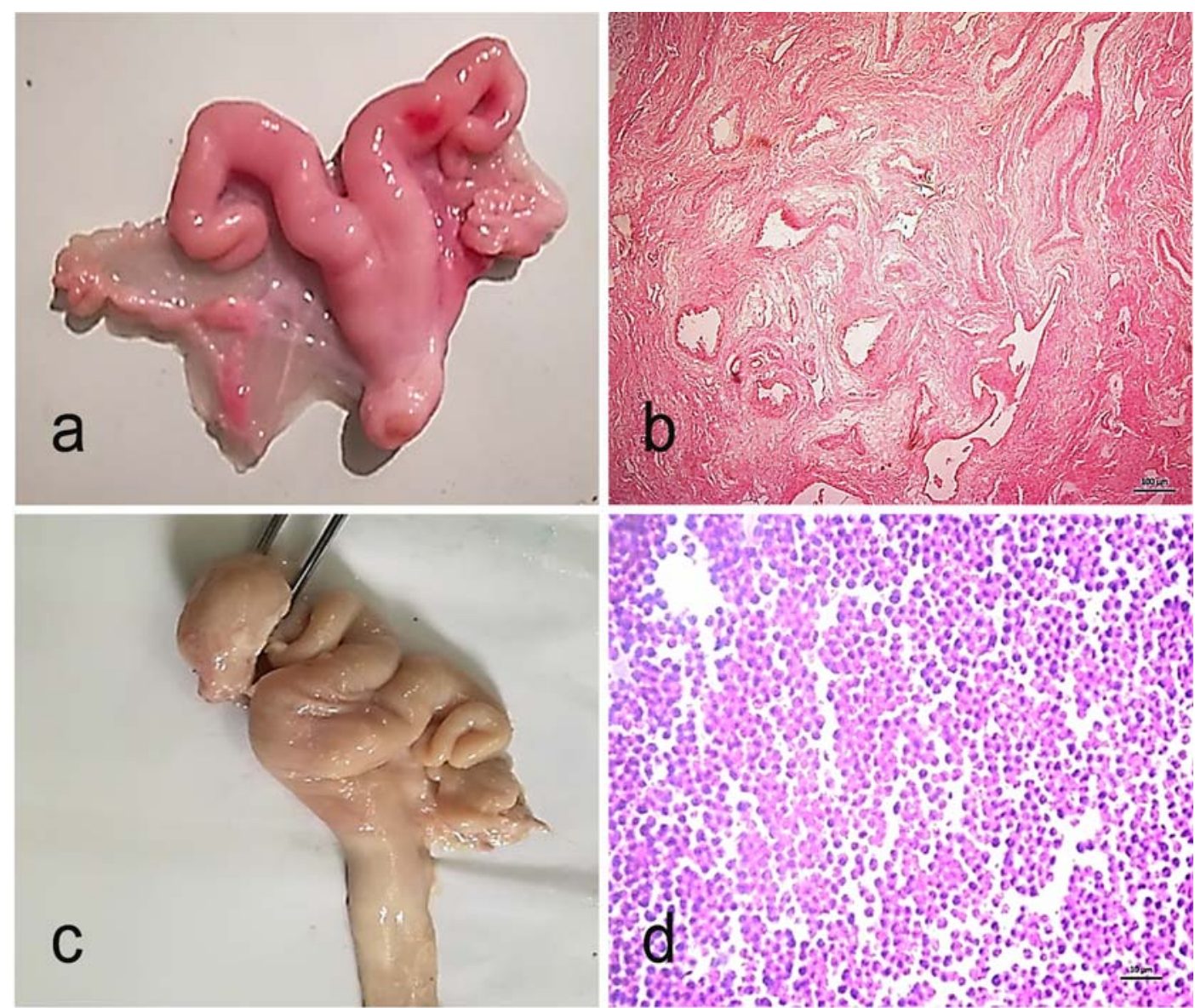

Fig. 3: Ovary of Black Bengal goat showing ovarian hypoplasia and tumour. Ovarian hypoplasia showing (a) small ovary devoid of well-developed follicles and corpus lutea and (b) microscopically, the ovarian stroma was fibrosed and the follicles were numerous, some of them cystic in appearance. (c) A large ovarian tumour showing oval growth with atrophy of the uterine tubes but solid and thickened in consistency, and (d) microscopically, neoplastic cells with hyper chromatic nuclei, mitosis and hypercellularity in the ovary.

Two cases of chronic oophoritis were recorded, characterized by hard consistency and smaller size than normal. There was an accumulation of mononuclear cells and proliferation of mature fibrous connective tissue in the stroma of the ovary. The prevalence of oophoritis (0.8\%) in Black Bengal goats was lower than the $3.9 \%$ reported by Rahman et al. (2010). 


\section{Fallopian tube}

Three cases of salpingitis were detected, where the fallopian tubes appeared swollen, blackish or grey and firmer in consistency. At histopathology, haemorrhages and neutrophils were seen in the lumen and wall of fallopian tubes. The prevalence of salpingitis (1.2\%) was higher than obtained by Nair and Raja (1972), 0.1\% and much lower than the values detected by Sattar and Khan (1988), 4.9\% and Rahman et al. (2010), 3.9\%.

One case of hydrosalpinx was detected: the fallopian tubes appeared more tortuous and distended with watery fluid. Microscopically the lumen was dilated and contained slightly pink proteinaceous material. One case of pyosalpinx was seen, characterized by dilatation of the fallopian tube with pus. Microscopically, the lumen of the fallopian tube carried neutrophils and proteinaceous material. A similar prevalence of hydrosalpinx and pyosalpinx was reported by Sattar and Khan (1988).

\section{Uterus}

Sub-acute and chronic endometritis were detected. Acute endometritis was characterized by necrosis, haemorrhages in caruncles, swollen and oedematous endometrium (Fig. 4a). Necrotic masses on the maternal caruncles of uterus were found. At histopathology, acute endometritis was characterized by necrosis, degeneration, oedema and capillary congestion of the lamina propria and submucosa. Neutrophil infiltration into the cotyledonary and intercotyledonary spaces and uterine glands indicated bacterial infection (Fig. 4b). Thickened endometrium and myometrium were seen in sub-acute endometritis. The uterus showed necrosis and firmer consistency of the uterine body especially at the maternal caruncles. Histopathological changes included mild haemorrhages in the endometrium and myometrium. There was infiltration of neutrophils, lymphocytes and macrophages beneath the mucosa. Proliferation of immature fibrous connective tissue in the endo and myometrium was found. All chronic endometritis was characterized by pale colour and harder consistency. On incision the caruncles appeared grey to brown. Large numbers of lymphocytes, macrophages and plasma cells were beneath the mucous layer. The lining of glandular tissues was distorted. In myometrium there was extensive proliferation of mature fibrous connective tissues with slight congestion of blood vessels. The occurrence of endometritis corresponded with the findings of Nair Raja (1972) and Jones et al. (1997). Overall occurrence appeared higher than observed by Nair and Raja (1972) $0.1 \%$; Srivastava et al. (1985) $0.3 \%$ and Ahmed (1993) $1.8 \%$.

All pyometra-affected uteri showed dilatation of uterine lumen containing cream coloured pus (Fig. 4c). Microscopically, the lumen of uterus was dilated and contained neutrophils (Fig. 4d). There was aggregation of neutrophils in endometrium as well as the lumen of endometrial glands. The prevalence of pyometra $(7.3 \%)$ in Black Bengal goat was higher than that of Ahmed (1993) who reported $1.4 \%$ pyometra in an 
abattoir survey and Neils et al. (2009) who observed 2.8\% pyometra in Red Sokoto goats.
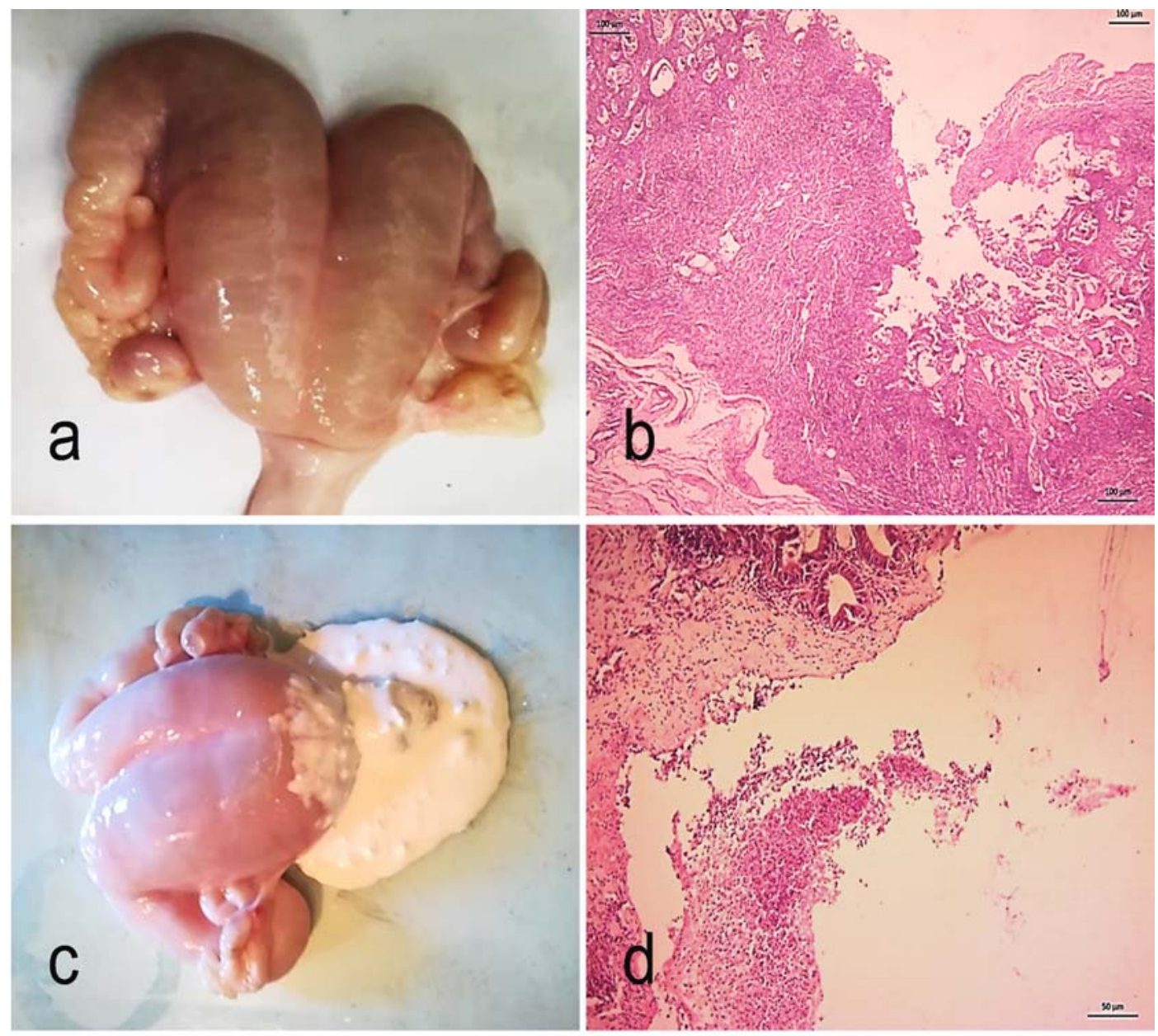

Fig. 4: Pathological conditions of uterus of Black Bengal goats. (a) Endometritis in goat showing swollen, oedematous and reddened uterus, and (b) necrosis, oedema and neutrophil infiltration in the lamina propria, submucosa and uterine glands. (c) Pyometra-affected uterus exuding cream coloured semi-solid pus and (d) neutrophil infiltration in the endometrium.

Hydrometra appeared as accumulation of watery fluid in the lumen of uteri, with the uterine horns swollen and oedematous (Fig. 5a) and the ovary enlarged. The uterus was dilated with light pink proteinaceous material attached to the mucosal lining of epithelia (Fig. 5b). In mucometra, the uterus became dilated with mucous secretions (Fig. 5c) and the ovary was enlarged. The uterine horns became thin and dilated with proteinaceous pink mucous secretion attached to the luminal surfaces (Fig. 5d). Mucometra $(1.6 \%)$ was similar to the finding of Biswas (2013) who recorded $2 \%$ mucometra in indigenous ewes. 


\section{Cervix}

Two cases of cervicitis were detected. The cervices were reddened, swollen, oedematous, and haemorrhagic with partial obliteration of lumen by haemorrhagic masses in acute cervicitis and a firmer consistency in chronic cervicitis (Fig. 6a). There was infiltration of mononuclear reactive cells, congestion and haemorrhages indicating acute cervicitis and proliferation of fibrous connective tissue in muscular layer of cervix with mild macrophage infiltration in the chronic case (Fig. 6a). The prevalence of cervicitis $(0.78 \%)$ was higher than the finding $(1.2 \%)$ of Khatun et al. (2007) and lower (3.9\%) than that of Rahman et al. (2010).
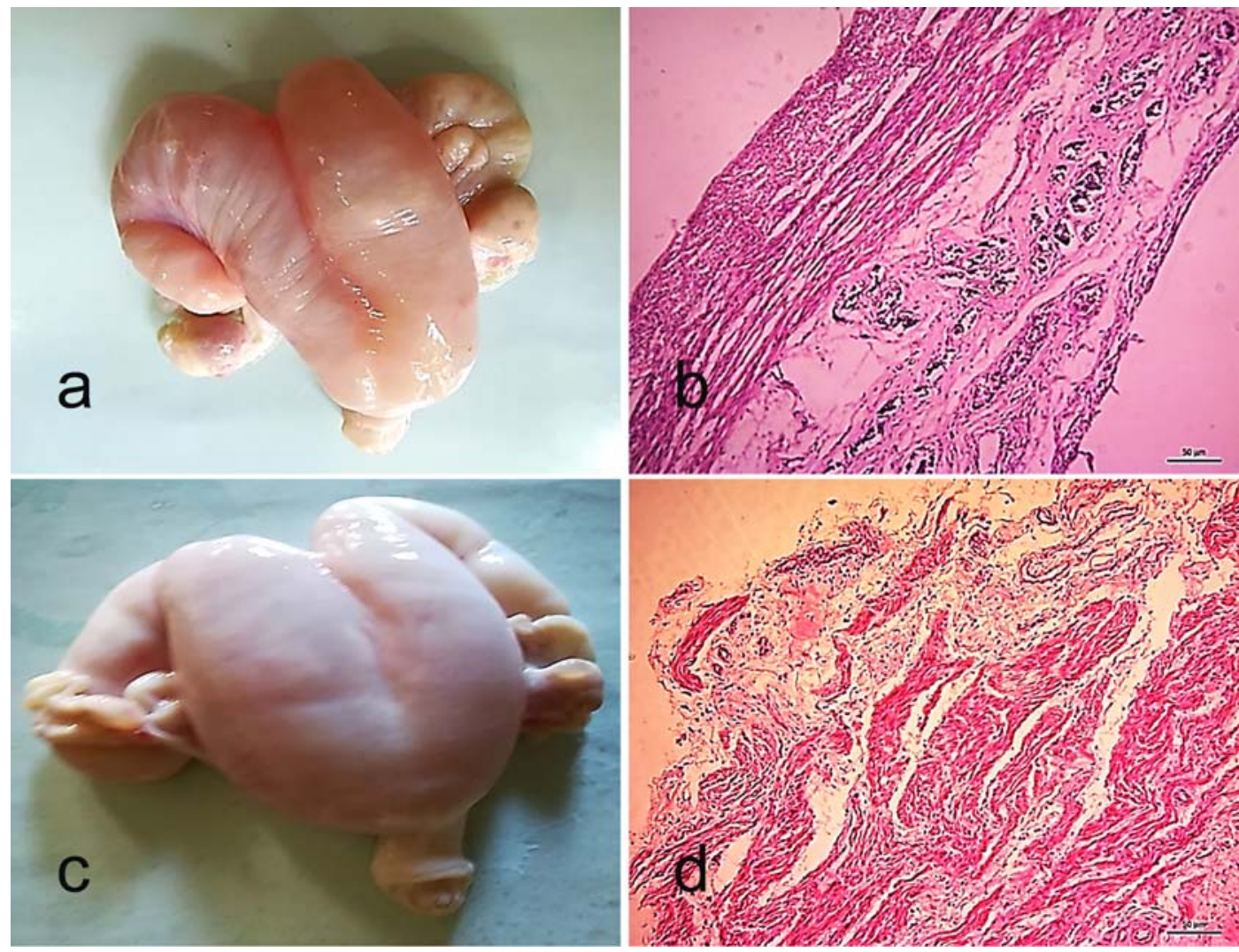

Fig. 5: Uterus of Black Bengal goats showing hydrometra and mucometra. Hydrometra in uterus showing (a) swollen uterine horns with thin and whitish endometrium surface, and (b) accumulation of light pink proteinaceous material attached to the mucosal lining of epithelia. Mucometra showing (c) dilated uterus with accumulation of mucous secretions, and (d) thin and dilated uterine horns with proteinaceous pink mucous secretion attached to the luminal surfaces.

\section{Vagina}

Granular vaginitis was detected in one case, with swollen, granular red lesions, and cloudy mucous exudate in the lumen (Fig. 6c). Microscopically, the epithelium and the lamina propria were moderately infiltrated with neutrophils and lymphocytes 
(Fig. 6d). Bartholin gland cyst was found once, $35 \mathrm{~mm}$ in diameter, located on left side of the floor of the vestibule of vagina, with redness and swelling of the vaginal floor indicating vaginitis. The cyst showed dilated wall composed of inner cuboidal epithelial cells and outer connective tissue layer. The lumen consisted of slightly pink proteinaceous material. The prevalence of vaginitis $(0.8 \%)$ was similar $(0.6 \%)$ to that described by Karadas and Timurkaan (2001).
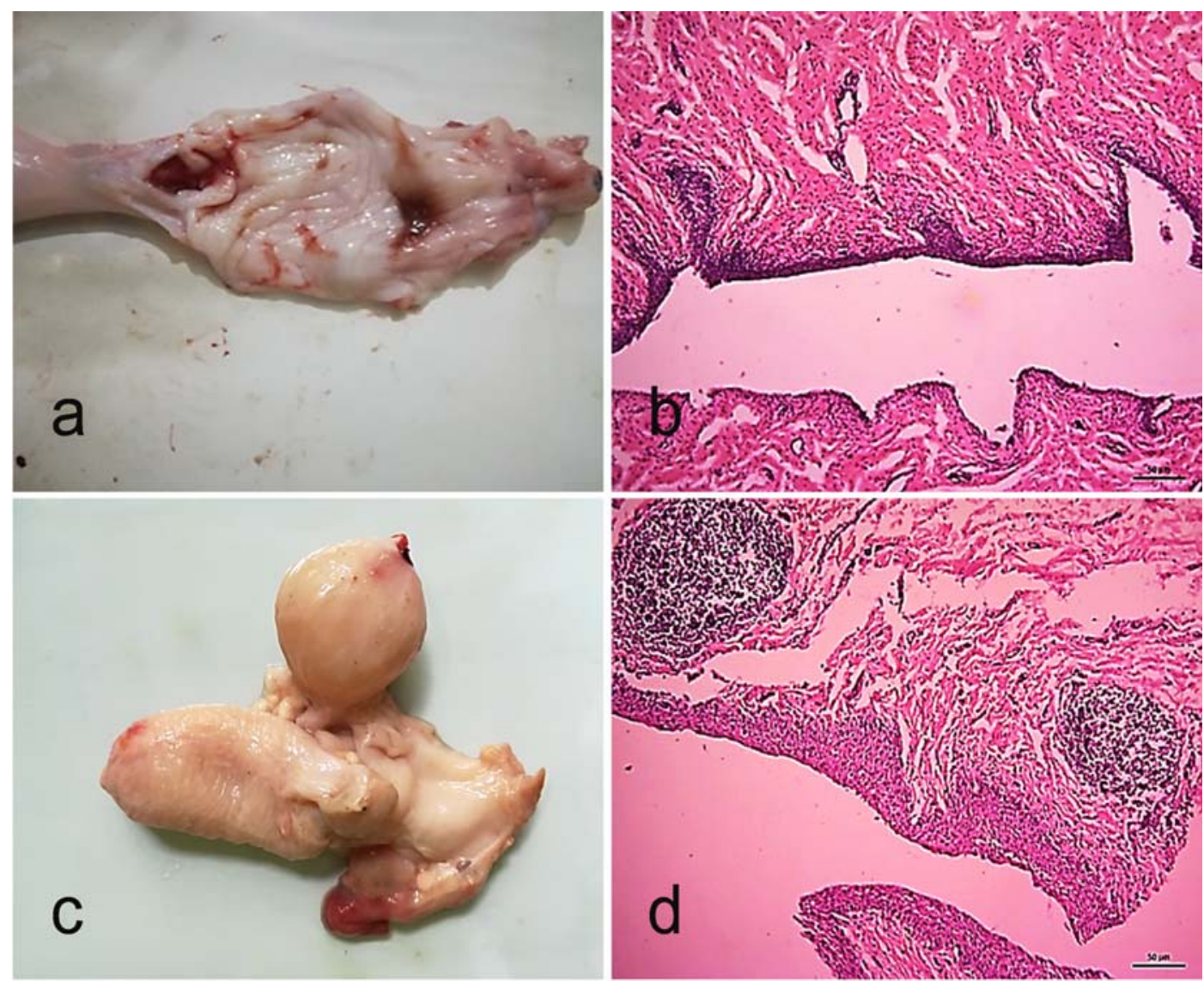

Fig. 6: Pathological conditions in the cervix and vagina of Black Bengal goats. (a) Cervicitis showing reddened, swollen cervix with haemorrhages in the lumen, and (b) Infiltration of mononuclear inflammatory cells with fibrous connective tissue in muscular layer of cervix. (c) Bartholin gland cyst containing clear fluid and attached on the left of the serosal wall of vagina, and (d) vaginitis characterized by neutrophil and lymphocyte infiltration in the epithelium of the vagina.

\section{Conclusions}

In the female reproductive system of Black Bengal goats in slaughterhouse materials luteal cyst, endometritis and pyometra were among the major pathological changes detected. Details of gross and microscopic changes of diseased reproductive tract were presented. 


\section{Acknowledgements}

The study was funded by Bangladesh Agricultural University Research System (BAURES).

\section{References}

Ahmed JU 1993: Incidence of gynaeco-obstetrical disorders in Black Bengal goats. Bangladesh Agricultural University Research Progress 7 499-505.

Ahmed S 2017: Sustainable goat farming for livelihood improvement in Bangladesh: Opportunities, constrains and potential. Dhaka: SAARC Agriculture Centre.

BBS 2019: Bangladesh Bureau of statistics. Ministry of Planning, Government of the Peoples' Republic of Bangladesh

Bhuiyan MJ, Hossain MI, Moslehuddin, Shahasuddin M 1988: Female reproductive disorders in Black Bengal goats of Bangladesh. Bangladesh Veterinarian 15 49-50.

Biswas HC 2013: Gross and histopathological study of reproductive tract of indigenous Ewe. MS Thesis, Bangladesh Agricultural University, Mymensingh.

Chand S, Chauhan HVS 1979: Pathology of female genital organs of sheep and goats in Haryana State. Indian Journal of Veterinary Pathology 3 23-25.

Das KK, Borgohain BN, Rajkonwar COK 1979: Note on the incidence of pathological conditions and histopathological changes in the female reproductive organs of local goats of Assam. Indian Journal of Animal Science 49 1009-1101.

Ferdous MR, Khan MJ, Rashid MA, Kamruzzaman M 2012: Effect of different levels of concentrate supplementation on the performance of Black Bengal goat. Bangladesh Journal of Animal Science 40 40-45.

Hasan MJ, Ahmed JU, Alam MM, Mojumder MLO, Ali MS 2015: Reproductive performance of Black Bengal goat under semi-intensive and extensive condition in Rajshahi district of Bangladesh. Asian Journal of Medical and Biological Research 1 22-30.

Jones TC, Hunt RD, King NW 1997: Veterinary Pathology. 6th edition, Williams and Wilkins. pp. 345.

Kadu MS, Kaikini AS 1988: Pathological conditions in the female genital organs of the goat. Indian Journal of Animal Science 58 795-798.

Karadas E, Timurkaan N 1999: Pathomorphologic investigations on the genital system of ewes I. Ovarium and oviduct. Turkish Journal of Veterinary and Animal Sciences 23 557-565.

Khatun A, Wani M, Choudhury AR, Khan MZ, Islam R, Pandit BA 2007: Incidence of reproductive abnormalities in small ruminants Izatnagar, India. Indian Journal of Animal Reproduction 28 53-56.

Luna LG. 1986: Manual of histologic staining methods of the Armed Forces Institute of Pathology. $3^{\text {rd }}$ ed., McGraw Hill, New York, USA. 
Lyngset O 1968: Studies on reproduction in goat. V. Pathological conditions and malformations of the genital organs of goat. Acta Veterinaria Scandanivica 9 364-375.

Nair KP, Raja CKSV 1972: Investigation on the pathological condition in the female genital organs. Kerala Journal of Veterinary Science 3 106-119.

Neils JS, Abdu PA, Sackey AKB 2009: Some reproductive disorders of the indigenous sheep and goats in Zaria, Northern Nigeria. Nigerian Veterinary Journal 30 46-50.

Rahman MH, Chowdhury EH, Saha SS, Islam A, Alam MGS 2010: Abattoir study of reproductive diseases in goats. Bangladesh Veterinarian 25 88-91.

Roy BJ, Hossain MM, Chowdhury EH, Biswas PIK, Hossain AKMA, Saha S 2001: Etiopathological investigation of systemic diseases in slaughtered Black Bengal goats. Bangladesh Veterinary Journal 35 67-73.

Sardar SA, Samad MA, Ehsan MA, Anower AKMM 2006: Incidence of goat diseases in the selected area of Dhaka and Mymensingh districts. Journal of Bangladesh Agricultural University 4 299-304.

Sattar A, Khan MZ 1988: Incidence and pathology of ovarian diseases of goats. Pakistan Veterinary Journal 3 18-21.

Srivastava AK, Patil VK, More BK 1985: Incidence of various disorders in local angora and crossbred goats. Indian Veterinary Journal 62 935-939. 